\title{
Analisis Struktur Gerak dan Fungsi Kesenian Pencak Silat Di Sanggar Putra Santana Desa Rajadatu Kabupaten Tasikmalaya
}

\author{
Titin Paridatul Fuadah, Asti Tri Lestari, Asep Wasta \\ Prodi Sendratasik Fakultas Keguruan dan Ilmu pendidikan, Universitas Muhammadiyah Tasikmalaya \\ Jl. Tamansari No. KM 2.5 Mulyasari Kec. Tamansari Tasikmalaya Jawa Barat \\ Email: paridatultitin22@gmail.com
}

\begin{abstract}
Abstrak
Penelitian ini bertujuan untuk menganalisis struktur gerak serta mendeskripsikan fungsi kesenian pencak silat Sanggar Putra Santana di Desa Rajadatu Kecamatan Cineam kabupaten Tasikmalaya. Penelitian ini menggunakan metode kualitatif dengan pendekatan deskriptif analitik. dengan teknik pengumpulan data menggunakan observasi, wawancara dan dokumentasi. Hasil dari penelitian ini yakni hasil analisis struktur gerak melalui jurus 10 yang memiliki nilai keagamaan sebagai makna yang terkandung dalam setiap gerakannya. Dengan struktur pertunjukan yang didukung oleh unsur pendukung lain, diantaranya Iringa music,rias dan busana, bentuk penyajian dan struktur pertunjukan. Hal tersebut menunjukan bahwa pencak silat memiliki kegunaan dan peranan penting dalam masyarakat terutama dalam fungsi yang ada didalamya diantaranya fungsi hiburan, ritual, presentasi estetis dan pendidikan. Dengan demikian bahwa penelitian ini dapat memberikan wawasan serta pemaparan sebagai deskripsi dari kesenian pencak silat.

Kata Kunci: Struktur Gerak, Fungsi dan Pencak Silat
\end{abstract}

\begin{abstract}
This study aims to analyze the structure of the movement and describe the function of the pencak silat arts Sanggar Putra Santana in Rajadatu Village, Cineam District, Tasikmalaya Regency. This study uses a qualitative method with an analytical descriptive approach. with data collection techniques using observation, interviews and documentation. The results of this study are the results of the analysis of the structure of the movement through 10 moves that have religious values as the meaning contained in each movement. With a performance structure that is supported by other supporting elements, including Iringa music, makeup and clothing, the form of presentation and the structure of the performance. This shows that pencak silat has an important use and role in society, especially in the functions it contains, including the functions of entertainment, rituals, aesthetic presentations and education. Thus, this research can provide insight and exposure as a description of the art of pencak silat.
\end{abstract}

Keywords: Movement Structure, Function and Pencak Silat

\section{A. Pendahuluan}

Kebudayaan Indonesia sangat beragam, masing-masing memiliki ciri khas yang berbeda-beda. Kebudayaan merupakan warisan yang tak ternilai harganya. Kebudayaan itu harus dilestarikan, dijaga, dan dimanfaatkan. Salah satu upaya untuk dapat melestarikan kebudayaan adalah dengan memperkenalkan dan mengajarkan budaya kepada generasi muda dengan tujuan kebudayaan tersebut bisa bertahan terus menerus mengikuti perkembangan zaman.

Hubungan antara manusia dengan kebudayaan merupakan satu kesatuan yang butuh, ketika manusia menciptakan kebudayaan, dan kebudayaan itu tercipta oleh manusia. Tidak dapat dipungkiri bahwasannya manusia dan kebudayaan tak terpisahkan, secara bersama-sama manusia menyusun kehidupan, menghimpun diri menjadi satuan sosial budaya dan menjadi masyarakat, kemudian melahirkan, menciptakan dan mengembangkan kebudayaan.

Salah satu unsur yang sangat berpengaruh dalam kebudayaan yaitu kesenian. Kesenian adalah bagian dari budaya serta merupakan sarana untuk mengekspresikan rasa keindahan dari dalam jiwa manusia. Berkesenian adalah salah satu kebutuhan hidup manusia 
dalam bentuk pemenuhuan kebutuhan akan rasa keindahan. Seni tidak lepas dari keberadaan unsur-unsur yang membangun karya seni tersebut. Sebuah pertunjukan seni di dalamnya terdiri atas bagian-bagian yang membentuk dan saling berkaitan satu sama lain. Keterkaitan bagian-bagian unsur dalam pertunjukan seni dapat menimbulkan kesan tertentu sehingga membentuk suatu struktur. Struktur adalah unsur pembentuk internal karya seni, misalnya; gerak, bentuk gerak, ragam gerak, pola dasar serta pola lantai.

Kesenian dapat dikatakan mempunyai struktur pertunjukan yang dalamnya terdapat ciri khas tertentu sesuai dengan tata aturan masyarakat pendukungnya. Struktur pertunjukan suatu kesenian dapat dilihat dari keterkaitan elemen-elemen yang membentuk karya seni tersebut, tata hubungan isi atau bentuk sajian pertunjukan dari karya seni dapat mewujudkan suatu nilai keindahan dari kesan masyarakat yang menyaksikannya. Ruang lingkup seni pertunjukan terdapat pada beberapa unsur dan cabang seni terutama seni tari. Dalam struktur pertunjukan kesenian tentu adanya berbagai macam struktur salah satu diantaranya yakni struktur gerak.

Gerak adalah media utama dalam sebuah tari, seperti diungkapkan oleh Soedarsono dalam Nusantara (2007:44) "substansi baku dari tari adalah gerak, dan gerak merupakan pengalaman fisik yang paling elementer dari kehidupan manusia". Pendapat tersebut dapat disimpulkan bahwa gerak sebagai bentuk pengalaman dari sebuah eksplorasi dari hasil pengamatan lingkungan.

Jawa Barat merupakan salah satu Provinsi di Indonesia yang memiliki berbagai jenis kesenian yang tersebar di Kota/Kabupaten. Berbagai kesenian daerah yang ada di Jawa Barat mempunyai bentuk serta ciri-ciri tersendiri sesuai dengan imajinasi dan kreatifitas masyarakat, Hal ini menunjukkan beragam pula jenis kesenian yang dimiliki tiap-tiap daerah. Salah satu di antaranya kesenian yang bersifat tradisional salah satunya yakni pencak silat. Menurut pendapat Abdus Sjukur, Pencak merupakan gerakan, langkah keindahan dengan menghindar yang disertakan gerakan berunsur komedi. Pencak dapat dipertontonkan Sebagai sarana hiburan. Silat merupakan unsur teknik bela diri menangkis, menetrang dan yang tidak dipergerakan di depan umum. Dalam arti bahwa pencak silat merupakan seni bela diri dengan gerak-gerak sebagai unsur didalamnya yang akan membentuk struktur gerak dengan jurus-jurus tertentu. Hal tersebut menjelaskan secara singkat mengenai pencak silat dari segi bentuk/Teks. Untuk isi/Konteks pencak silat itu sendiri tentunya ada hal yang melatar belakangi lahirnya pencak silat itu sendiri.

$\mathrm{Di}$ Tasikmalaya ada banyak perguruan pencak silat dengan nama yang berbeda-beda. Semua gerakan dan jurus-jurusnya memiliki kesamaan, dari mulai sikap kuda-kuda, sikap pasang, sikap tangkisan, sikap pukulan, hindaran dan lain sebagainya, secara turun temurun hingga banyak akarnya, maka terciptalah nama-nama perguruan yang banyak di jumpai di Tasikmlaya, salah satunya yaitu Kesenian Pencak Silat Di Sanggar Putra Santana yang berada di Kampung Garunggang, RT 05 RW 01 Desa Rajadatu, Kecamatan Cineam, Kabupaten Tasikmalaya.

Melalui kesenian pencak silat di Sanggar Putra Santana penelitian ini merupakan upaya dalam mengungkap dan mendeskripsikan struktur gerak sebagai bahan pengenalan gerak-gerak dasar dan susunan gerak dalam bentuk 
pertunjukan serta mengungkap fungsi kesenian pencak silat sebagai informasi dan wawasan mengenai peranan dan kegunaan kesenian pencak silat itu sendiri.

\section{B. Metode Penelitian}

Metode penelitian adalah sebuah langkah atau cara untuk mendapatkan suatu data atau kebenaran yang dilakukan secara sistematis berdasarkan logika dan fakta. Metode sangat diperlukan dalam penelitian, karena dalam melakukan penelitian kita perlu mengikuti aturan atau kaidah yang berlaku, agar hasil penelitian yang diperoleh dapat dikatakan valid dan dapat terarahkan. Dalam mendapatkan hasil yang sesuai diinginkan, maka perlu adanya metode atau pendekatan dalam penelitian yang tepat. Adapun metode yang akan digunakan dalam penelitian ini adalah metode kulaitatif dengan pendekatan deskriptif analitik.

Menurut Masyhuri dkk, (2011 : 22) penelitian kualitatif itu berakar pada latar ilmiah sebagai kebutuhan, mengandalkan manusia sebagai alat penelitian, memanfaatkan metode kualitataif, mengadakan analisis data secara indukatif, mengarahkan sasaran penelitiannta pada usaha menemukan teori dari dasar, bersifat deskriptif, lebih mementingkan proses dari pada hasil, membatasi studi dengan fokus, memiliki seperangkat kriteria untuk memeriksa keabsahan data, rancangan penelitiannya bersifat sementara, dan hasil penelitiannya disepakati oleh kedua belah pihak peneliti dan subjek peneliti.

\section{Hasil Penelitian dan Pembahasan}

\section{Struktur Gerak Pencak Silat}

Pencak silat di Sanggar Putra Santana memiliki bentuk pertunjukan yang menjadi sebuah rangkaian pertunjukan, diantaranya yakni bubuka, inti penutup.
Pada bagian bubuka terdapat tatalu dan nada kombinasi, pada bagian inti masuk pada pertunjukan yakni tepak 2, tepak paleredan, ibing bubuka tunggal putri, ibing rampak, ibing garuda. Pada bagian penutup terdapat soder/baksa, karena pada bagian ini penonton ikut berinteraksi menunjukan kemampuannya dalam pencak silat. Ditutup dengan ibing rampak sebagai tanda selesainya pertunjukan pencak silat.

Ketiga rangkaian tersebut tersusun sebagai berikut :
a. Tatalu
b. Nada Kombinasi
c. Tepak 2
d. Tepak Paleredan
e. Ibing bubuka tunggal putri (tepak 2)
f. Ibing rampak (tepak 2 palered)
g. Ibing garuda
h. Soder/baksa dipirig oleh lagu-lagu sunda klasikan
i. Ibing Rampak panutup

Pada gerak pencak silat di Sanggar Putra Santana terdapat Jurus 10 merupakan ciri khas jurus dalam metode ajar pemula/murid yang baru masuk ke perguruan silat Sanggar Putra Santana. Jurus 10 pada umumnya terdapat di perguruan lain namun tidak dijadikan ciri khas untuk meode ajar, dan jurus 10 juga merupakan sebagaian jurus yang terdapat pada aliran Cimande, karena Sanggar Putra Santana dalam pencak silat berkiblat pada aliran Cimande. Melalui ke sepuluh jurus ini Sanggar Putra Santana memiliki ciri khas yang berbeda dalam metode ajar pemula dalam menguasai teknik gerak dan dasar gerak dalam pencak silat.

Jurus-jurus tersebut memiliki nilai dan makna, salah satunya keagamaan, karena Sanggar Putra Santana berkembang pada wilayah yang berdampingan dengan pondok pesantren. Sehingga pada 
perkembangannya terjadi akulturasi antara kesenian dengan konteks agama didalamnya. Hal tersebut ditunjukan dalam setiap gerak jurus 10, yakni :

1. Jurus Keupeul

2. Jurus Teundeud

3. Jurus Jeblag

4. Jurus Beset

5. Jurus Giles

6. Jurus Tamplok

7. Jurus Liliwatan

8. Jurus Colok

9. Jurus Potong

10. Jurus Seuseup

Ke 10 jurus tersebut diambil pada beberapa struktur gerak yang ada pada tepak 2 paleredan dan tepak 3 paleredan. Sehinggan susunan jurus tersebut tidak baku di terapkan pada serangkaian gerak tepak 2 dan tepak 3. Namun hanya digunakan beberapa jurus saja sebagai ciri khas bahwa di Sanggar Putra Santana dalam mengkemas tepak 2 dan tepak 3 tetap menggunakan jurus 10 dari metode ajar pemula. Sehingga dapat cepat dipahami dalam serangkaian pertunjukan bagia semua kalangan.

Konteks keagamaan sebagai makna di dalam setiap jurus ditunjukan melalui 3 jurus yakni jurus keupeul, teundeud dan seuseup. Ketiga jurus ini ditunjukan dengan setiap gerak yang diawali dengan sikap seperti berdo'a yang mana disisipkan nilai luhur keagamaan dengan maksud bahwa setiap kegiatan diawali dengan bedo'a, dipercaya akan lebih berkah dan segala sesuatu dilancarkan.

\section{Fungsi Kesenian Pencak Silat}

Pencak silat merupakan kesenian yang kedudukannya memiliki peranan penting dalam masyarakat. Pencak silat diterapkan dalam kehidupan yakni sebagai bela diri dan juga berperan dalam memelihara kesehatan jasmani dan rohani, mewujudkan rasa estetika budaya, serta menyalurkan aspirasi spiritual manusia. Dalam arti bahwa pencak silat tidak hanya berhubungan dengan fisik manusia melainkan berhubungan dengan jiwa manusia dalam melatih kekuatan tenaga dalam, yang dapat dikendalikan. Hal tersebut menunjukan bahwa pencak silat berperan penting dalam kehidupan masyarakat.

Selain itu pencak silat memiliki kegunaan dan fungsi sebagai kesenian tradisional sesuai dengan teori Soedarsono (2002:126) yang mengungkapkan bahwa fungsi kesenian terbagi menjadi tiga, diantaranya kesenian tradisional sebagai sarana ritual,kesenian tradisional sebagai hiburan pribadi dan fungsi seni pertunjukan sebagai presentasi estetis.

Pencak silat sebagai seni di Sanggar Putra Santana ini yakni pencak silat sebagai penggerak seni pada wilayah tersebut, sehingga masyarakat mengenal sebuah kesenian yang dianggap paling tua dan sangat bermanfaat untuk keberlangsungan perkembangan kesenian dan kebudayaan diwilayah sekitar. Dan masyarakat sangat berantusias mengikuti serangkaian kesenian pencak silat yang pada saat ini banyak mengalami perkembangan dan berbagai macam jenis pertunjukan didalamnya. Mulai dari adanya sisipan yakni tari-tarian yang dikolaborasikan dengan pencak silat. Yang mana pada saat ini pencak silat sudah termasuk pada cabang seni tari dengan elemen utama gerak dan pelaku. Tari-tarian tersebut diantaranya, tari topeng bodoran, tari garuda dan tari-tarian lainnya. Sehingga pencak silat di Sanggar Putra Santana merupakan ujung tombak kesenian di wilayah tersebut.

\section{Kesimpulan}

Struktur gerak pencak silat di Sanggar Putra Santana merupakan salah satu elemen pokok dalam pertunjukan 
yang dihasilkan oleh tubuh manusia terutama pada pertunjukan pencak silat merupakan sebuah seni sebagai media ungkap bela diri, yang memiliki jurus yang diterapkan sebagai metode ajar pemula dalam mempelajari pencak silat yang ada di Sanggar Putra Santana, jurus tersebut merupakan jurus 10, yang diantaranya adalah jurus keupel, teundeud, jeblag, beset, giles, tamplok, liliwatan, colok, potong, seuseup.

Jurus-jurus tersebut memiliki maknamakna yang menunjukan kearah keagamaan, karena Sanggar tersebut mengalami akulturasi antara kesenian dan keagamaan didalamnya. Sehingga pada perkembangan gerak dalam pencak silat di Sanggar tersebut tidak terlepas dari makna dan slmbol dalam keagaamaan didalamnya.

Pada bentuk pertunjukan pencak silat dibagi dalam tiga bagian yakni bubuka, inti dan penutup. Pada bubuka terdapat tatalu dan nada kombinasi, pada inti terdapat pertunjukan pencak silat dari mulai tepak dua sampai ibing rampak, pada penutup terdapat soder/baksa sebagai media interaksi pelaku dan penonton.

Disamping Pencak silat di Sanggar Putra Santana sebagai media interaksi antara pelaku dan penonton tentunya pencak silat digolongkan pada bebrapa fungsi yakni, fungsi upacara ritual, fungsi hiburan dan fungsi presentasi estetis serta fungsi pendidikan .
Fungsi upacara yang ada meliputi kegiatan sebelum memulai latihan dan memulai pertunjukan adanya do'a bersama serta penghargaan pada roh leluhur. Hal ini berguna sebagai bentuk hubungan dengan sang pencipta (Habluminallah) dalam meminta kelancaran dan keselamatan. Karena pada dasarnya dzat yang maha kuasa lebih berkuasa diatas segalanya.

Fungsi hiburan pencak silat sebagai sarana merefleksikan diri melalui sajian pertunjukan. Hal ini berguna sebagai sarana apresiasi diri dalam mendalami kreativitas dan ketenangan jiwa melalui kesenian tradisional. Sehingga kesenian mampu meningkatkan kesenangan dan ketenangan jiwa.

Fungsi presentasi estetis dalam kesenian ini untuk mempresentasikan atau mempertunjukkan kesenian yang estetis atau untuk dinikmati nilai keindahannya dan juga diartikan sebagai seni kolektif. Hal ini berguna dalam emmperkenalkan kesenian tradisional sebagai bentuk sarana sosialisasi kebudayaan melalui kesenian.

Fungsi seni sebagai media pendidikan sebagai sarana menambah ilmu dan wawasan mengenai pencak silat melalui metode ajar dengan ciri khas 10 jurus. Hal ini berguna untuk menambah wawasan masyarakat dalam mengenal dan mendalami ilmu bela dri melalui kesenian tradisional.

\section{Daftar Pustaka}

Afifuddin. 2009. Metodologi Penelitian Kualitatif. Bandung: CV Pustaka Setia.

Ari Wulandari. 2011. Batik Nusantara: makna filosofis, cara pembuatan dan industry batik. Yogyakarta: Andi.

Arikunto, S. 2006. Metode Penelitian Kualitatif. Jakarta: Bumi Aksara

Banoe, P.(2003). Kamus Musik Yogyakarta : Kanisius.

Ediyono, S., \& Widodo, S. T. (2019). Memahami Makna Seni dalam Pencak Silat. Surakarta: Panggung Vol. 29 No. 3.

Heryana, A. (2018). Pencak Silat Ameng Timbangan Di Jawa Barat, Hubungan Antara Ajaran Dan Gerak Ameng Timbangan. Bandung: Patanjala Vol. 10 No. 1. 
Husna , N., Kurnita Taat, \& Hartati, T. (2017). Fungsi dan Penyajian Tarian Ratoh Deuk Pada Sanggar Seni Seulaweuet. Banda Aceh: Jurnal IImiah FKIP UNSYIAH.

Koentjaraningrat. 2000. Pengantar Ilmu Antropologi. Jakarta : Rineka Cipta

Komaruddin. (2001). Ensiklopedia Manajemen, Edisi ke 5. Jakarta. Bumi Aksara

Maryono, O. (2017).Pencak Silat untuk Generasi Penerus. Jakarta: Yayasan Pustaka Obor Indonesia.

Masyhuri dan Zainuddin, (2011). Metode Penelitian-Pendekatan Praktis dan Aplikatif. Bandung: PT Refika Aditama.

Noer, A. G. (2019). Perubahan Struktur Penyajian dan Fungsi Kesenian Bangreng Pada Lingkung Seni Giri Asih Di Kecamatan Salawu. Tasikmalaya: Magelaran.

Ruslan, A. I. (n.d.). Analisis Struktur Gerak Tari Radat Koko Kecamatan Sejangkung Kabupaten Sambas. Pontianak .

Rosyadi. (2012). Angklung: Dari Angklung Tradisional ke Angklung Modern. Bandung: Balai Pelestarian Sejarah dan Nilai Tradisional Bandung.

Saaduddin, H. (2015). Fungsi Sandiwara Amal di Masyarakat Desa Pulau Belimbing, Kec Bangkinang Barat, Kab Kampar Provinsi

si Riau. Palembang: Jurnal Ekspresi Seni Vol. 17, No. 1.

Sandi , A. A. (2017). Pencak Silat Sebagai Sistem (Studi Kasus Pencak Silat Pangean). Pekanbaru: JOM FISIP Vol. 4 No.1.

Setiawan , I. (2011). Eksistensi Pencak Silat di Kabupaten Purwakarta (Kajian tentang Strategi Adaptasi). Bandung: Patanjala Vol.3 No. 3.

Soedarso, Sp. (1990). Tinjauan Seni. Yogyakarta: Saku Dayar Sarana.

Sucipto. (2001). Pendekatan Keterampilan Taktis dalam Pembelajaran Pencak Silat. Jakarta: Direktorat Jenderal Olahraga

Wahyono, H. (2005). Makna dan Fungsi Teori dalam Proses Berpikir Ilmiah dan dalam Proses Penelitian Bahasa. Magelang. 